the Government has not found a way of improving the competitiveness of this once important industry. It is hard to escape the conclusion that everybody would have been better off if the money spent on helping the industry with special purchases of machine tools had been spent instead in government laboratories on a programme of research and development agreed in advance with those companies within the industry willing to undertake the vigorous exploitation of anything that might result but without the payment of royalties. Where computers are concerned, it is still not too late to hope that the great government laboratories preoccupied with defence electronics should be set to work on the kind of research and development that might in due course make an efficient computer industry in Britain. The trouble is that such a programme would not merely offend the Treasury's belief in the sanctity of public money but that it also requires that the Department of Trade and Industry be equipped to make a much more hard-headed appraisal of the value of research and development than it is at present. And although there is no reason why the National Research and Development Corporation should not continue to exist, it is plainly time to recognize that it cannot make any useful contribution to the strategic developments now urgently needed.

\section{Congressional Assessment}

For close on a decade the United States Congress has modestly acknowledged its incapacity to settle complicated technical questions by the normal committee procedure and for much of that time it has been clamouring for some means of carrying out what is now called technology assessment. If there are no mistakes between now and the pre-election recess, Congress should at some point next year be provided with a form of apparatus for the evaluation of proposals for spending money on technological innovations of one kind or another (see page 186). The scheme for setting up a technology assessment unit, originally advocated by $\mathrm{Mr}$ Emilio Q. Daddario in his days as Chairman of the Sub-Committee on Science, Research and Development in the House of Representatives, has been improved as the years have drifted. It is entirely sensible that if there has to be such an organization, it should be equipped to commission studies from the many organizations in the United States, in universities and non-profit institutions, which have in the past few years become skilled at work like this. At the same time, however, Congress will be leading itself up the garden path if it thinks that technology assessment will do much to simplify the process of deciding whether new schemes for spending public money are free from the unanticipated side-effects which have made it fashionable, in Congress as well as outside, to suppose that technology has become a hazardous influence on society.

The recent history of the supersonic air-transport project should be a sufficiently vivid reminder. To begin with, the arguments against the spending of public money on the SST were largely economic. Was it right that the Administration and the Boeing Company should have settled for an aircraft designed to fly at three times the speed of sound and for all the technological complications, which that decision entailed-titanium alloys in the aircraft skin and complicated joints for altering the attitude of the wings? And was it sensible, in any case, to think that airlines would equip themselves with such aircraft so soon after buying Jumbo jets and at a time (two years ago) when the growth of airline traffic appeared less buoyant than it had been and has since become? Senator William Proxmire did a useful public service in bringing out the uncertainties in the economic case for building SSTs, and it still remains a puzzle to know how the airlines proposed to turn round huge supersonic transports in just over an hour at the end of each leg of a journey. Undoubtedly it would have helped Congress if there had been an independent organization able to dissect the errors in the Administration's case, but it is hard to think that in a field where uncertainties are commonplace, such as this, any independent economic assessment would have satisfied the putative aircraft manufacturers and their sponsors in the government. It might have clarified the issues and made them sharper, but that is all.

Other objections to the SST project would have been as difficult for the Technology Assessment Panel to grapple with as other independent people have since discovered. How serious will be the effect of sonic booms? What precisely will be the effects on the upper atmosphere of large fleets of supersonic transports plying their way along the air routes of the world? Although there is now good reason to believe that predictions of serious consequences have been exaggerated, the proof of what the side-effects will be will come only several years from now, when supersonic aircraft are in regular service. So would the Technology Assessment Panel have had more to say than that there is an urgent need for more research? And would such a conclusion have affected the way in which Congressmen and Senators voted on the allocation of funds by the Administration? Is it not much more probable that the decisive influences would have been precisely what they turned out to be-political. No doubt the decision, just over a year ago, to abandon the SST project in the United States would have gone the other way if there had been more reason to think that either Concorde or the Tu144 would have been a serious threat to the international supremacy of American aircraft manufacturers. And it remains a fact that what Congress eventually decided stemmed as much from its wish to show the White House who was boss as from a belief in the judicial permanence of its decision.

\section{Nature's Parish}

ALL journals welcome a vigorous correspondence column, and Nature is no exception. Moreover, there is a sense in which uninhibited correspondence can enormously enhance the sense of community which journals and newspapers create among their readers and which, in the long run, is what they are for. In this spirit, it is entirely welcome that Nature should be used as a means of ventilating the accumulated grievances among British astronomers, which is why it is natural that Professor Burbidge's complaint two weeks ago about the organization of observational astronomy should have been published-and it is a little odd that so far it has evoked only the most muted (and verbal) comments. In exactly the same way, there is no doubt that comments on the 